\title{
Pengaruh PAD, DAU, dan SILPA terhadap Perilaku Oportunistik Penyusunan Anggaran pada Pemerintahan Daerah Kabupatan dan Kota di Provinsi Sumatera Utara
}

\author{
Novian Paisal Sitompul \\ Universitas Sumatera Utara \\ paisalnoviansitompul@gmail.com
}

\begin{abstract}
Abstrak
Penelitian ini bertujuan untuk menguji dan mengetahui pengaruh PAD, DAU dan SILPA terhadap perilaku oportunistik penyusunan anggaran pada pemerintahan daerah Kabupaten dan Kota Di Provinsi Sumatera Utara. Populasi dalam penelitian ini adalah seluruh pemerintahan daerah Kabupaten dan Kota Di Provinsi Sumatera Utara. Metode pengambilan sampel yang digunakan adalah purposive sampling. Berdasarkan kriteria sampel maka jumlah sampel dalam penelitian sebanyak 15 Kabupaten dan Kota Di Provinsi Sumatera Utara. Metode pengumpulan data dalam penelitian ini adalah menggunakan data sekunder. Data yang digunakan yaitu realisasi APBD yang meliputi PAD, DAU, SiLPA, belanja pendidikan, kesehatan, pekerjaan umum, hibah dan bantuan sosial tahun 2011-2016. Teknik analisis yang digunakan adalah analisis regresi berganda. Hasil penelitian menunjukkan bahwa PAD secara parsial tidak berpengaruh signifikan terhadap perilaku oportunistik penyusunan anggaran pada pemerintahan daerah Kabupaten dan Kota Di Provinsi Sumatera Utara. DAU secara parsial berpengaruh signifikan terhadap perilaku oportunistik penyusunan anggaran pada pemerintahan daerah Kabupaten dan Kota Di Provinsi Sumatera Utara. Silpa secara parsial berpengaruh signifikan terhadap perilaku oportunistik penyusunan anggaran pada pemerintahan daerah Kabupaten dan Kota Di Provinsi Sumatera Utara. PAD, DAU dan Silpa secara simultan berpengaruh signifikan terhadap perilaku oportunistik penyusunan anggaran pada pemerintahan daerah Kabupaten dan Kota di Provinsi Sumatera Utara.
\end{abstract}

Kata Kunci: Pendapatan Asli Daerah, Dana Alokasi Umum, Silpa dan Perilaku Oportunistik Penyusunan Anggaran 


\section{PENDAHULUAN}

Proses penyusunan anggaran merupakan tahap yang cukup rumit dan mengandung unsur politis. Selama proses penyusunan anggaran terjadi perebutan kepetingan dari berbagai pihak, baik legislatif, eksekutif, partai politik melalui kadernya di legislatif, organisasi masyarakat, pengusaha, dan rakyat kecil. Disinilah permasalahan dalam penyusunan anggaran muncul yaitu adanya miss allocatian anggaran. Adanya peluang untuk memenuhi kepentingan pribadi dan kelompok yang menguntungkan pihak tertentu dan kesempatan melakukan korupsi (Latifah, 2010:87). Dugaan adanya miss allocation dalam anggaran terjadi karena politisi memiliki kepentingan pribadi dalam penganggaran. Alokasi sumberdaya dalam anggaran mengalami distorsi ketika politisi berperilaku korup, terutama terkait dengan peluang untuk mendapatkan keuntungan pribadi pada proyek-proyek yang akan dibiayai dengan anggaran pemerintah, yakni pengalokasian akan lebih banyak untuk proyek-proyek yang mudah dikorupsi dan memberikan keuntungan politis bagi politisi. Terjadinya misalokasi dalam anggaran belanja pemerintah terkait dengan perilaku oportunistik politisi dan aparat pemerintah. Besarnya kewenangan legislatif dalam proses penyusunan anggaran membuka ruang bagi legislatif untuk memaksakan kepentingan pribadinya. Untuk merealisasikan kepentingan pribadinya, legislatif akan merekomendasikan eksekutif untuk menaikkan alokasi pada sektor-sektor yang mendukung kepentingannya. Legislatif cenderung mengusulkan pengurangan atas alokasi untuk pendidikan, kesehatan dan belanja publik lainnya yang tidak bersifat job programs dan targetable (Halim, 2011:57).

PAD pada tahun 2011 meningkat sampai tahun 2016 sebesar 3,524,308 juta, hal ini menunjukkan ketika besaran alokasi belanja untuk legislatif dikaitkan dengan kemampuan keunggulan daerah (diukur dari besaran PAD) secara tidak langsung memberi motivasi kepada legislatif untuk membuat misalokasi anggaran belanja. Dalam penentuan PAD legislatif akan mendorong eksekutif untuk selalu meningkatkan target sehingga dapat meningkatkan alokasi untuk program yang mendukung kepentingannya. Hal ini ditengarai sebagai perilaku oportunistik.

Pada data yang ada di tabel 1.1 menunjukkan bahwa DAU pada tahun 2011 meningkat sampai tahun 2016 sebesar 12,116,336 juta. Dengan demikian kenaikan jumlah DAU dapat dimanfaatkan sebagai ruang untuk mengusulkan alokasi belanja yang baru, yang bisa berbeda dengan prioritas pengalokasian pada tahun sebelumnya. Peluang perilaku oportunistik lain ditengarai juga terjadi pada sumber pendapatan daerah yang berbentuk dana transfer pemerintah pusat, contohnya adalah Dana Alokasi Umum (DAU). DAU adalah dana yang bersumber dari pendapatan APBN yang dialokasikan dengan tujuan pemerataan kemampuan keuangan antar-Daerah untuk mendanai kebutuhan Daerah dalam rangka pelaksanaan Desentralisasi. Berkaitan dengan perimbangan keuangan antara pemerintah pusat dan daerah, hal tersebut merupakan konsekuensi adanya penyerahan kewenangan pemerintah pusat kepada pemerintah daerah. DAU 
berperan sebagai pemerata fiskal antardaerah (fiscal equalization) dengan memperhatikan potensi daerah, luas daerah, keadaan geografi, jumlah penduduk dan tingkat pendapatan masyarakat di daerah. Menurut Sularso (2014:5) bahwa DAU merupakan block grant yakni hibah yang penggunaannya cukup fleksibel atau tidak terikat dengan program pengeluaran tertentu.

Masalah lain dalam pengalokasian anggaran adalah tidak diperhatikannya jangka waktu penetapan perubahan APBD, yang biasanya dilakukan beberapa bulan sebelum berakhirnya tahun anggaran. Hal ini menjadikan anggaran tidak efektif atau bahkan tidak terserap sepenuhnya saat tahun anggaran berakhir, dan berdampak pada tingginya SiLPA (Sisa Lebih Perhitungan Anggaran), dimana dana yang seharusnya dapat digunakan untuk peningkatan kesejahteraan rakyat ternyata tidak terserap sepenuhnya, hal ini dapat dilihat pada data yang ada di tabel 1.1 juga menunjukkan bahwa SILPA pada tahun 2011 meningkat sampai tahun 2016 sebesar 23,515,432 juta.

SiLPA ini memiliki pengaruh pada pengalokasian APBD periode selanjutnya, karena SiLPA akan digunakan untuk menyeimbangkan anggaran yaitu dengan menutupi pengeluaran pembiayaan. SiLPA juga bisa terjadi akibat asimetri informasi antara eksekutif dan legislatif.

Berdasarkan (https://www.tobasatu.com), anggaran pendapatan dan belanja Daerah (APBD) Sumatera Utara Anggaran 2017 yang saat ini tengah dibahas DPRD Sumut bersama Pemprovsu dinilai tidak berpihak pada rakyat. Sebab dalam struktur APBD 2017 sebesar Rp.12 triliun lebih, banyak digunakan untuk anggaran belanja tidak langsung yakni sebesar Rp.8,752 triliun dimana 3,090 miliar diantaranya digunakan untuk belanja pegawai. Sementara untuk belanja langsung digunakan untuk membiaya pembangunan setahun ke depan hanya dianggarkan Rp.4,282 triliun lebih dan sisa lebih penggunaan anggaran (Silpa) taun 2016 sebesar Rp.942 miliar. Itu artinya, uang rakyat hanya terkuras untuk membiayai gaji pegawai negeri sipil, sehingga porsi anggaran untuk pembangunan menjadi lebih kecil.

Penelitian ini menggunakan pengukuran Perilaku Oportunistik Penyusunan Anggaran (OPA) Parwati (2015) yang merupakan pengembangan dari pengukuran Perilaku Oportunistik Penyusunan Anggaran (OPA) yaitu dengan menghilangkan peningkatan anggaran legislatif dan menggantinya dengan peningkatan belanja hibah dan bansos dari tahun sebelumnya ke tahun berjalan. Apalagi saat ini mantan Gubernur Sumatera ditetapkan menjadi tersangka dan sedang menjalani persidangan terkait kasus dana bansos. Penelitian-penelitian terdahulu tersebut menunjukkan bahwa peningkatan Pendapatan Asli Daerah, Sisa Lebih Perhitungan Anggaran (SiLPA), dan Dana Alokasi Umum berpengaruh terhadap perilaku oportunistik penyusunan anggaran.

Hasil penelitian Parwati (2015) menyatakan bahwa SiLPA berpengaruh negatif terhadap perilaku oportunistik legislatif. Hal ini yang mendorong peneliti melakukan penelitian. Saat ini di Indonesia banyak mantan maupun anggota 
legislatif aktif serta pejabat pemeritah yang divonis bersalah oleh pengadilan karena penyalahgunaan APBD. Kemungkinan hal ini terkait dengan peran legislatif dan eksekutif yang sangat besar dalam penganggaran, terutama pada tahap perencanaan atau perumusan kebijakan anggaran dan pengesahan anggaran hingga pengalokasiannya.

Fenomena perilaku penyusun anggaran sangat menarik untuk diteliti lebih lanjut, karena meskipun aturan formal tentang mekanisme penyusunan APBD telah dirancang sedemikian rupa, namun pada prakteknya masih terjadi beberapa penyimpangan. Untuk itu dipandang perlu penjelasan lebih mendalam tentang perilaku oportunistik legislatif dan juga eksekutif dalam penganggaran publik. Dengan melihat hal-hal tersebut diatas maka penulis tertarik untuk meneliti faktor-faktor yang menentukan Perilaku Oportunistik Legislatif dan Eksekutif dalam Penganggaran Daerah.

\section{Pendapatan Asli Daerah}

\section{LANDASAN TEORI}

Adalah pendapatan yang diperoleh dari sumber-sumber pendapatan daerah dan dikelola sendiri oleh pemerintahan daerah (Bastian, 2012).

\section{Dana Alokasi Umum}

Adalah dana yang berasal dari APBN, yang dialokasikan dengan tujuan pemerataan kemampuan keuangan antar-Daerah untuk membiayai kebutuhan pengeluarannya dalam rangka pelaksanaan desentralisasi. (Darise, 2008).

\section{Silpa}

Adalah sisa lebih realisasi penerimaan dan pengeluaran anggaran selama satu periode anggaran. (Erlina, 2008)

\section{Perilaku Oportunistik Penyusunan Anggaran}

Adalah perilaku yang berusaha mencapai keinginan dengan segala cara bahkan cara ilegal sekalipun.

(Sularso, 2014).

\section{METODE PENELITIAN}

Penelitian asosiatif yang merupakan penelitian yang dilakukan untuk mencari hubungan antara satu variabel dengan variabel yang lainnya. Populasi dalam penelitian ini adalah beberapa APBD Kabupaten/Kota di Provinsi sumatera utara yang terdiri dari 10 kabupaten/ kota untuk kurun waktu 2011-2016. Sumber data dalam penelitian ini diperoleh dari situs Direktorat Jenderal Perimbangan Keuangan Kementerian Keuangan yaitu www.djpk.depkeu.go.id. Pengumpulam data dilakukan dengan metode dokumentasi, yaitu metode mengumpulkan data sekunder yang berasal dari laporan keuangan pemerintah Kabupaten dan kota di Provinsi Sumatera Utara. Pengolahan data menggunakan perangkat lunak SPSS 16.0For Windows. Analisis statisitk inferensial dalam penelitian ini meliputi: uji asumsi klasik, regresi analisis jalur, uji hipotesis. 


\section{HASIL DAN PEMBAHASAN \\ Pengaruh PAD Terhadap OPA}

Hasil penelitian ini menunjukkan bahwa PAD tidak berpengaruh signifikan terhadap OPA. Pembahasan dalam penelitian ini dinyatakan bahwa ketika besaran alokasi belanja untuk legislatif dikaitkan dengan kemampuan keunggulan daerah (diukur dari besaran PAD) secara tidak langsung memberi motivasi kepada legislatif untuk membuat misalokasi anggaran belanja. Menurut Bastian (2012), pendapatan asli daerah merupakan pendapatan yang diperoleh dari sumbersumber pendapatan daerah dan dikelola sendiri oleh pemerintahan daerah. Pendapatan daerah juga merupakan pendapatan yang diperoleh oleh pemerintah daerah dan digali dari potensi pendapatan yang ada di daerah. Dengan kata lain pendapatan asli daerah merupakan pendapatan yang diterima oleh pemerintah daerah atas segala sumber-sumber atau potensi yang ada pada daerah yang harus diolah oleh pemerintah daerah didalam memperoleh pendapatan daerah. Dalam penentuan PAD legislatif akan mendorong eksekutif untuk selalu meningkatkan target sehingga dapat meningkatkan alokasi untuk program yang mendukung kepentingannya. Hal ini ditengarai sebagai perilaku oportunistik.

\section{Pengaruh DAU Terhadap OPA}

Hasil penelitian ini menunjukkan bahwa DAU berpengaruh signifikan terhadap OPA. Pembahasan dalam penelitian ini dinyatakan bahwa DAU adalah dana yang bersumber dari pendapatan APBN yang dialokasikan dengan tujuan pemerataan kemampuan keuangan antar-Daerah untuk mendanai kebutuhan Daerah dalam rangka pelaksanaan Desentralisasi. Berkaitan dengan perimbangan keuangan antara pemerintah pusat dan daerah, hal tersebut merupakan konsekuensi adanya penyerahan kewenangan pemerintah pusat kepada pemerintah daerah. Menurut Darise (2008), Dana Alokasi Umum (DAU) adalah dana yang berasal dari APBN, yang dialokasikan dengan tujuan pemerataan kemampuan keuangan antar-Daerah untuk membiayai kebutuhan pengeluarannya dalam rangka pelaksanaan desentralisasi. kenaikan jumlah DAU dapat dimanfaatkan sebagai ruang untuk mengusulkan alokasi belanja yang baru, yang bisa berbeda dengan prioritas pengalokasian pada tahun sebelumnya. Peluang perilaku oportunistik lain ditengarai juga terjadi pada sumber pendapatan daerah yang berbentuk dana transfer pemerintah pusat, contohnya adalah Dana Alokasi Umum (DAU). DAU adalah dana yang bersumber dari pendapatan APBN yang dialokasikan dengan tujuan pemerataan kemampuan keuangan antar-Daerah untuk mendanai kebutuhan Daerah dalam rangka pelaksanaan Desentralisasi. Berkaitan dengan perimbangan keuangan antara pemerintah pusat dan daerah, hal tersebut merupakan konsekuensi adanya penyerahan kewenangan pemerintah pusat kepada pemerintah daerah. DAU berperan sebagai pemerata fiskal antardaerah (fiscal equalization) dengan memperhatikan potensi daerah, luas daerah, keadaan geografi, jumlah penduduk dan tingkat pendapatan masyarakat di daerah. Menurut Sularso (2014:5) bahwa DAU merupakan block grant yakni hibah yang penggunaannya cukup fleksibel atau tidak terikat dengan program pengeluaran tertentu. 


\section{Pengaruh SILPA Terhadap OPA}

Hasil penelitian ini menunjukkan bahwa SILPA berpengaruh signifikan terhadap OPA. Pembahasan dalam penelitian ini dinyatakan bahwa SiLPA juga bisa terjadi akibat asimetri informasi antara eksekutif dan legislatif. SiLPA ini memiliki pengaruh pada pengalokasian APBD periode selanjutnya, karena SiLPA akan digunakan untuk menyeimbangkan anggaran yaitu dengan menutupi pengeluaran pembiayaan. Menurut Erlina (2008), Sisa Lebih Perhitungan Anggaran (SiLPA) adalah sisa lebih realisasi penerimaan dan pengeluaran anggaran selama satu periode anggaran. Jika tidak diperhatikannya jangka waktu penetapan perubahan APBD, yang biasanya dilakukan beberapa bulan sebelum berakhirnya tahun anggaran. Hal ini menjadikan anggaran tidak efektif atau bahkan tidak terserap sepenuhnya saat tahun anggaran berakhir, dan berdampak pada tingginya SiLPA (Sisa Lebih Perhitungan Anggaran), dimana dana yang seharusnya dapat digunakan untuk peningkatan kesejahteraan rakyat ternyata tidak terserap sepenuhnya.

\section{KESIMPULAN}

Berdasarkan analisis hasil studi dan pembahasan tentang flypaper effect pada unconditional grant dan pendapatan asli daerah terhadap belanja daerah pada Kabupaten Deli Serdang, dapat ditarik simpulan bahwa PAD secara parsial tidak berpengaruh signifikan terhadap perilaku oportunistik penyusunan anggaran pada pemerintahan daerah Kabupaten dan Kota Di Provinsi Sumatera Utara, sedangkan DAU dan SILPA secara parsial berpengaruh signifikan terhadap perilaku oportunistik penyusunan anggaran pada pemerintahan daerah Kabupaten dan Kota Di Provinsi Sumatera Utara. Secara simultan, PAD, DAU dan SILPA berpengaruh signifikan terhadap perilaku oportunistik penyusunan anggaran pada pemerintahan daerah Kabupaten dan Kota Di Provinsi Sumatera Utara.

\section{REFERENSI}

Abdullah, S. dan Asmara, J.A, 2010. Perilaku Oportunistik Legislatif Dalam Penganggaran Daerah: Bukti Empiris atas Aplikasi Agency Theory di Sektor Publik. Makalah Simposium Nasional Akuntansi 9.

Bastian, Indra, 2012. Sistem Akuntansi Sektor Publik, Edisi Kedua. Salemba Empat. Jakarta.

Erlina, (2008). Akuntansi Sektor Publik : Akuntansi untuk Satuan Kerja Perangkat Daerah (SKPD). USU Press : Medan.

Erlina, Sri Mulyani, 2007. Metodologi Penelitian Bisnis : Untuk Akuntansi dan Manajemen, Cetakan Pertama, USU Press, Medan.

Gumiadi, Aan. (2016). Determinan Perilaku Oportunistik Penyusunan Anggaran (Studi Pada Kabupaten/ Kota di Provinsi Jawa Timur). Universitas Muhammadiyah Surakarta.

Halim, Abdul \& Syukriy Abdullah, 2011. "Hubungan dan Masalah Keagenan di Pemerintahan Daerah: Sebuah Peluang Penelitian Anggaran dan Akuntansi'. Jurnal Akuntansi Pemerintah Volume 2, Nomor 1, hal 53-64. 
https://www.tobasatu.com/2017/01/09/apbd-sumut-2017-tidak-pro-rakyat-darirp12-triliun-hanya-rp42-t-digunakan-untuk-pembangunan/

Latifah, Nurul, 2010. Adakah Perilaku Oportunistik Dalam Aplikasi Agency Theory di Sektor Publik? Is there of Opportunistic Behavior on the Agency Theory Aplication in the Public Sector. Fokus Ekonomi Volume 5 No. 2 Desember $2010: 85-94$

Maryono, Riky. (2013). Pengaruh Perubahan Dana Alokasi Umum Terhadap Perilaku Oportunistik Legislatif Dalam Penganggaran Daerah. Universitas Negeri Padang.

Megasari, Ida Ayu Gede Sutha. (2015). Pengaruh Pendapatan Asli Daerah, Selisih Lebih Perhitungan Anggaran Dan Flypaper Effect Pada Perilaku Oportunistik Penyusun Anggaran. Universitas Udayana, Bali, Indonesia.

Parwati, S.M, 2015. Perilaku Oportunistik Penyusunan Anggaran. Universitas Udayana.

Republik Indonesia, 2006. Peraturan Menteri Dalam Negeri Republik Indonesia No.13 tahun 2006 tentang Pedoman Pengelolaan Keuangan Daerah.

Republik Indonesia, 2011. Peraturan Menteri Dalam Negeri Republik Indonesia No. 21 tahun 2011 tentang Perubahan Kedua Atas Peraturan Menteri Dalam Negeri Nomor 13 Tahun 2006 Tentang Pedoman Pengelolaan Keuangan DaerahPemerintahan Daerah.

Romarina, A. dan A. Makfatih. 2010. Faktor-Faktor Risiko Fiskal dan Penganggaran Daerah. Jurnal BPPK Volume I.

Suartini, Ni Kadek Ayu. (2016). Determinan Perilaku Opportunistic Penyusun Anggaran Calon Incumbent Terkait Pilkada Serentak Tahun 2015. Universitas Udayana (Unud), Bali, Indonesia.

Sugiyono (2014), Metode Peneiltian Kuantitatif Kualitatif dan R\&D. Alfabeta: Bandung.

Sularso, Havid, Yanuar E. Restianto dan Astari Elka Istiqomah. 2014. Determinan Perilaku Oportunistik Penyusunan Anggaran (Studi Pada Kabupaten/Kota di Jawa Tengah). Makalah Simposium Nasional Akuntansi 17 Mataram, Lombok. 